Rodríguez, A., Alfaro, E. J., \& Cortés, J. (2021). Spatial and temporal dynamics of the hydrology at Salinas Bay, Costa Rica, Eastern Tropical Pacific. Revista de Biología Tropical, 69(Suppl. 2), S105-S126. https://doi. org/10.15517/rbt.v69iS2.48314

\title{
Spatial and temporal dynamics of the hydrology at Salinas Bay, Costa Rica, Eastern Tropical Pacific
}

\author{
Alejandro Rodríguez ${ }^{1,2}$; (iD https://orcid.org/0000-0003-4618-6560 \\ Eric J. Alfaro $1,2,3$; (iD https://orcid.org/0000-0001-9278-5017 \\ Jorge Cortés ${ }^{1,4}$; (D) https://orcid.org/0000-0001-7004-8649
}

1. Centro de Investigación en Ciencias del Mar y Limnología (CIMAR), Ciudad de la Investigación, Universidad de Costa Rica, 11501-2060, San José, Costa Rica; alejandro.rodriguez_b@ucr.ac.cr, erick.alfaro@ucr.ac.cr, jorge.cortes@ucr.ac.cr

2. Escuela de Física, Sede Rodrigo Facio, Universidad de Costa Rica, 11501-2060, San José, Costa Rica

3. Centro de Investigaciones Geofísicas (CIGEFI), Ciudad de la Investigación, Universidad de Costa Rica, 11501-2060, San José, Costa Rica

4. Escuela de Biología, Sede Rodrigo Facio, Universidad de Costa Rica, 11501-2060, San José, Costa Rica

Received 08-I-2021. Corrected 20-III-2021. Accepted 10-V-2021.

\begin{abstract}
Introduction: Salinas Bay is located in the warm pool of the Eastern Tropical Pacific (ETP), characterized by warm, shallow surface waters, a strong and shallow thermocline, and an important biological diversity. The primary productivity of the region is influenced by the coastal upwelling, which occurs during the boreal winter as a result of the strengthening of trade winds.

Objective: To study the spatial and temporal dynamics of physical and chemical parameters at seven hydrographic stations in Salinas Bay, Costa Rica, through the analysis of CTD data, and relate the warm and cold events to the regional atmospheric conditions present when measuring the data.

Methods: Seven hydrographic stations, sampled at Salinas Bay between August 2008 and December 2014, were selected. The variables processed for analysis are temperature, density, salinity, oxygen, chl-a and turbidity. Once the data was processed, 42 Hovmöller kind diagrams were plotted.

Results: All variables, except turbidity, presented a seasonal periodicity associated with the upwelling. In general, colder and denser waters, higher salinity and chl-a concentrations and lower dissolved oxygen values were observed during the dry season, when the upwelling was active. Whereas, during the rainy season water masses were warmer and less dense, salinity and chl-a concentrations decreased and dissolved oxygen values tended to increase.

Conclusions: The spatial and temporal dynamics of the hydrology in Salinas Bay was influenced by the coastal upwelling events. The region also presented an interannual variability associated with ENSO. Seasonal and interannual variability can counteract their effects on the oceanographic parameters when they coincide temporally.
\end{abstract}

Key words: upwelling; transisthmian wind; CTD; Papagayo; synoptic conditions.

The Eastern Tropical Pacific (ETP) has a warm pool characterized by high temperature and low salinity surface waters with a strongshallow pycno and thermocline (Fiedler \&
Lavín, 2017; Fiedler \& Talley, 2006). This habitat supports a biological diversity that includes reef-building corals, plankton communities, fishes, marine mammals, and birds, among 
others. Salinas Bay is located a few kilometers north of the Gulf of Papagayo. Climate drivers and forcers are the same in both places, with very similar seasonal cycles (Alfaro \& Cortés, 2012; Alfaro et al., 2012; Amador et al., 2006; Amador, Durán-Quesada, et al., 2016; Amador, Rivera, et al., 2016). The dimensions of Salinas Bay are small and being in a position such that its axis is east-west, it is directly influenced by the exit towards the Pacific of the Papagayo jet, which flows in the lowlands south of Nicaragua and north of Costa Rica with a predominantly northeast direction (Amador et al., 2006). Therefore, primary productivity is affected by seasonal upwelling events in Salinas Bay, as is the case in at least three other coastal areas of the ETP: the gulfs of Tehuantepec, Papagayo and Panama (Amador et al., 2006). The upwellings are caused by wind forcing over the sea surface near the coast, at gaps where transisthmian wind jets reach the Pacific through topographic depressions of the mountain range (Amador, Rivera, et al., 2016; Fiedler \& Lavín, 2017). Those wind jets are generated by northeasterly trade winds and easterlies winds that increase atmospheric pressure in the Caribbean (Amador, DuránQuesada, et al., 2016; Kessler, 2006; Willet, Leben, \& Lavín, 2006). The upwellings take place during boreal winter, which corresponds to dry season in the Central American Pacific slope (Amador et al., 2006), and they reach their maximum intensity between February and March (Brenes, Lavín, \& Mascarenhas, 2008). The cold fronts in the boreal winter intensify trade winds, strengthening the Papagayo wind jet, which forces the coastal upwelling (Alfaro \& Cortés, 2012; McCreary, Lee, \& Enfield, 1989; Zárate-Hernández, 2013). Furthermore, Intertropical Convergence Zone (ITCZ) migration southward favors the predominance of northeasterly trade winds in Central America during the dry season (Brenes \& Gutiérrez, 1998). The ETP is also under the influence of interannual variability sources, such as the El Niño-Southern Oscillation (ENSO) warm/ cold cycle (Alexander, Seo, Xie, \& Scott, 2012; Fiedler \& Lavín, 2017). Interannual variability impact on sea surface temperature (SST) anomalies, in upwelling regions in the Central American Pacific, is mainly attributed to ENSO (Alfaro \& Lizano, 2001). Alfaro et al. (2012) found a relationship between warm events in Culebra Bay, Gulf of Papagayo, and anomalies in the Niño 3.4 index.

The development of an upwelling is evidenced by the spatial and seasonal dynamics of the thermocline depth and the thermohaline pattern in the water column (Brenes \& Gutiérrez, 1998; Fiedler \& Talley, 2006). D'Croz and O'Dea (2009) consider that the upwelling is "one of the most pervasive hydrological events to influence the shelf waters of Pacific Central America". Intense winds displace sea surface water offshore and set up vertical mixing in the surface layers of the sea, allowing colder thermocline and subthermocline water to rise toward the surface, which results in lower SSTs and higher salinity concentrations (Alfaro \& Cortés, 2012; Brenes, Hernández, \& Gutiérrez, 1998; Kessler, 2006; Willet et al., 2006). CTD data measured by a research cruise, between February and March 1994, exposed the upwellings in the Gulf of Papagayo and Gulf of Panama, where high salinity cold tongues surrounded by warm waters were observed on the surface (Brenes et al., 2008). According to Loza-Álvarez, Benavides-Morera, Brenes-Rodríguez, and Saxon Ballestero (2018), temperatures were lower and salinity concentrations were higher in a sampling carried out in the Gulf of Papagayo during the dry season than in another sampling during the wet season. In hydrographic stations at the ETP during March, there was a notable elevation of the thermocline associated with the strong Papagayos winds (Mora-Escalante, Lizano, Alfaro, \& Rodríguez, 2019). In the Gulf of Papagayo, high concentrations of nutrients, carbon dioxide $\left(\mathrm{CO}_{2}\right)$ and phytoplankton from the subsurface chlorophyll maximum emerge into the euphotic zone during the upwelling, increasing local chlorophyll production (Ballestero \& Cohen, 2004; Willet et al., 2006; Rixen, Jiménez, \& Cortés, 2012). Loza-Álvarez et al. (2018) also found that chl-a maximum 
at $35 \mathrm{~m}$ in the rainy season was replaced by a homogeneous distribution with higher chl-a concentrations in shallow waters during the dry season, as a consequence of the turbulent mixture caused by the winds and the upwelling processes. At Panama Bay, the upwelling displaces nutrient-poor surface water with cooler, more saline and nutrient rich waters (D'Croz \& Robertson, 1997). In the Gulf of Panama, increases in chl-a and dissolved oxygen concentrations were observed at the surface, followed by oxygen-poor waters below the thermocline and higher turbidity, as a result of upwelling events (D'Croz \& O’Dea, 2007, 2009).

The alterations in the physico-chemical parameters of the water caused by the upwellings affect biological populations. Increases in nutrient availability triggers phytoplankton blooms (Stuhldreier, Sánchez-Noguera, Rixen, et al., 2015); however, in the Gulf of Papagayo, Stuhldreier, Sánchez-Noguera, Roth, Jiménez, et al. (2015) observed that at the Matapalo reef the upwelling did not influence the benthic community. Wizemann et al. (2018) found that carbonate bioerosion increased with the upwelling in that same area. However, Rixen et al. (2012) determined that in Culebra Bay, Gulf of Papagayo, the negative impact of the upwelling on coral growth might be counteracted by high nutrient concentrations. Sanchéz-Noguera et al. (2018) suggest that corals in Culebra Bay are adapted to upwelling effects, in accordance with Stuhldreier, Sánchez-Noguera, Roth, Cortés, et al. (2015). In fact, Jiménez, Bassey, Segura, and Cortés (2010) described coral habitats in the Gulf of Papagayo, since most of the coastal area is suitable for coral reef growth despite the upwelling influence. Conversely, the conditions are not suitable for the growth of coral reefs in Panama Bay due to upwelling effects, according to D'Croz and Robertson (1997). Increases in nutrient concentrations caused by upwelling events in ETP are associated with the expansion of opportunistic species in coral reefs (Roth, Stuhldreier, Sánchez-Noguera, Carvalho, \& Wild, 2017). Regarding the study area of this research, Sibaja-Cordero and Cortés (2008) detected a seasonal change of algal assemblages in the rocky intertidal zone related to the upwelling in Salinas Bay. Moreover, Cortés, SamperVillarreal, and Bernecker (2014) discovered that the growth rate of an algae, Sargassum liebmannii, peaked during seasonal upwelling in Salinas Bay.

Summing-up, within the ETP areas of contrast are created between upwelling and non-upwelling zones, as well as seasonality, which defines the marine ecology of the Central American Pacific. As a result, a study of the spatial and temporal dynamics of the physical parameters in Salinas Bay is necessary to understand the influence of upwelling events on the hydrology and biology of the bay. Accordingly, the objective of this research is to produce the first report of the spatial and temporal dynamics of temperature, density, salinity, oxygen, chl-a and turbidity in Salinas Bay, Costa Rica, based on the analysis of CTD cast data measured through 33 one-day oceanographic campaigns, between August 2008 and December 2014, and relate the CTD warm and cold events to the observed atmospheric conditions.

\section{MATERIALS AND METHODS}

Study area: Salinas Bay is located on the northwest of Costa Rica and is shared with Nicaragua. This region is exposed to a seasonal upwelling that starts in December and ends in April-May. There are small coral patches, constructed by the zooxanthellate corals. Filtering organism are some of the main components of the rocky bottoms, including several species of ascideans, sea cucumbers, polychaets and octocorals (Cortés, 2016). Eight hydrographic stations were sampled along a latitudinal transect $11.8 \mathrm{~km}$ long, at $11.06^{\circ} \mathrm{N}$ latitude and between $85.67^{\circ} \mathrm{W}$ and $85.79^{\circ} \mathrm{W}$ longitude (Fig. 1).

Measurements and analyses: A CTD database made up of 215 data-points was compiled from the results of 33 one-day oceanographic campaigns, conducted in Salinas Bay between August 2008 and December 2014 


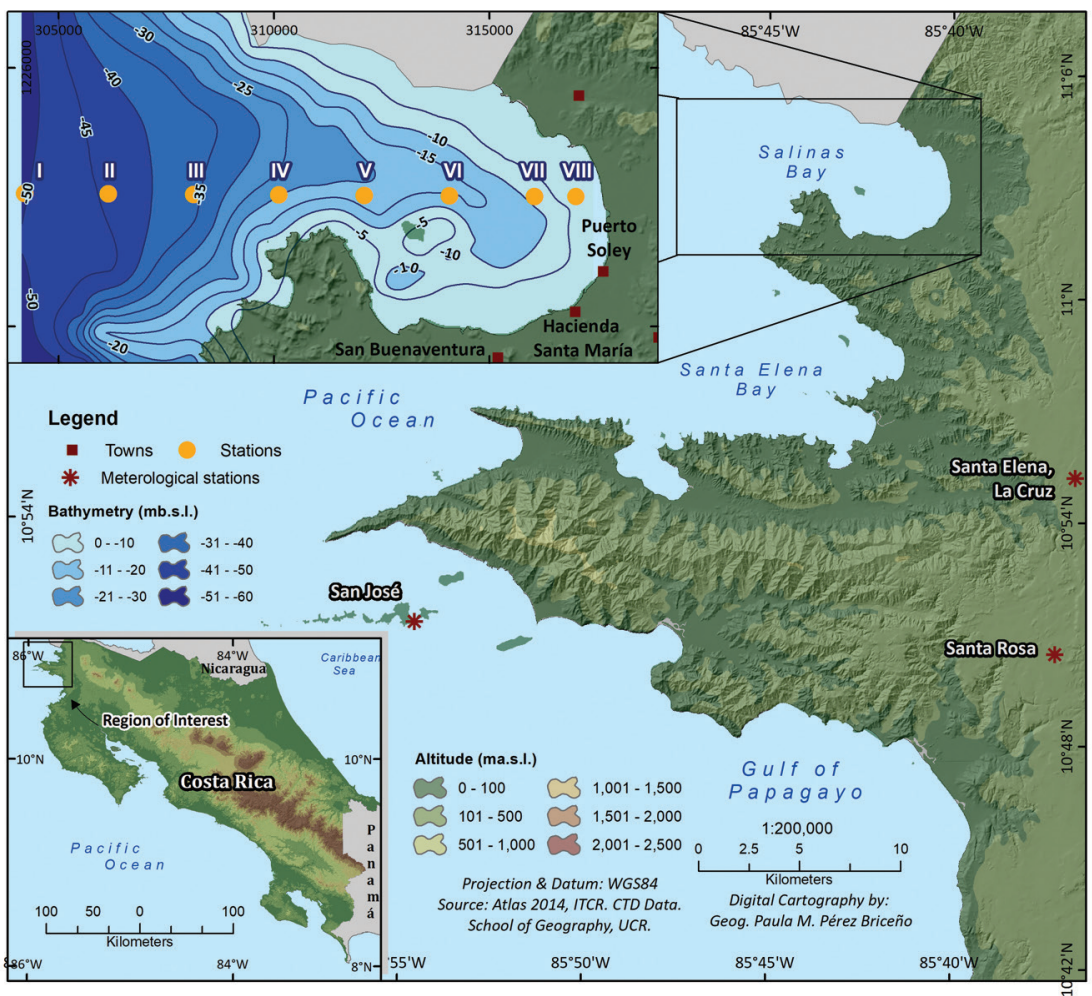

Fig. 1. Location of Salinas Bay with respect to some geographic reference points in the North Pacific of Costa Rica and location of CTD sampling stations within Salinas Bay.

(Table 1). The physical parameters of the water were measured with a CTD model SBE 19plus V2, which was calibrated under the manufacturer's standards. In some campaigns, it was not possible to obtain measurements for all the stations and/or variables and certain data measured were excluded because they were not reliable. After the analysis of maximum and minimum values listed in Table 2, Table 3, Table 4, Table 5, Table 6 and Table 7, data from the closest station to the coast (VIII) were discarded from this research, since it was too shallow and sampling could not be done some times or the data were unreliable. The maximum depth sampled in each station fluctuates for the different campaigns due to variations in

TABLE 1

Dates of oceanographic campaigns at Salinas Bay, Costa Rica

\begin{tabular}{|c|c|c|c|c|c|c|c|c|c|c|c|c|}
\hline \multirow{2}{*}{ Year } & \multicolumn{12}{|c|}{ Month } \\
\hline & Jan & Feb & Mar & Apr & May & Jun & Jul & Aug & Sep & Oct & Nov & Dec \\
\hline 2008 & & & & & & & & 20 & & 25 & & 4 \\
\hline 2009 & & 19 & & 23 & & 18 & & 20 & & 22 & & \\
\hline 2010 & 7 & & & & 6 & 24 & & 19 & & 21 & & 10 \\
\hline 2011 & & 24 & & 14 & & 23 & & 18 & & & & 8 \\
\hline 2012 & & 15 & & 25 & & 14 & & 23 & & 18 & & 5 \\
\hline 2013 & & 13 & & 18 & & 13 & & & & & & 5 \\
\hline 2014 & & & 20 & & & 12 & & & 18 & & & 4 \\
\hline
\end{tabular}


sea level that could be caused by environmental conditions, such as the tide and the season. As a result, an approximation of the maximum depth was used for data plots (Fig. 2, Fig. 3, Fig. 4, Fig. 5, Fig. 6, and Fig. 7). The approximate maximum measurement depth at station I was $50 \mathrm{~m}$, at station II $45 \mathrm{~m}$, at station III $35 \mathrm{~m}$, at station IV $25 \mathrm{~m}$, at station V $19 \mathrm{~m}$, at station VI $18 \mathrm{~m}$ and at station VII $10 \mathrm{~m}$.

The variables processed for analysis were temperature, density, salinity, oxygen, chl-a and turbidity. The raw data were downloaded from the CTD and subjected to a series of processes included in Sea-Bird Electronics SBE Data Processing software that converted the raw data to engineering units, subjected to a low-pass filter some columns of the data, aligned the data relative to pressure, performed conductivity thermal mass correction, deleted inaccurate values, calculated the derive variables, averaged the data every meter deep, generated the data to ASCII files and plotted preliminary profiles of the variables. Regarding derived variables, the density of seawater and practical salinity were computed with SBE software from CTD measurements (Sea-Bird Electronics, 2016). Dissolved oxygen concentration computation was based on values measured by a polarographic membrane oxygen sensor model SBE 43, which counts the number of oxygen molecules per second through the membrane (Sea-Bird Electronics, 2013). Chl-a and turbidity were measured with the ECO-FL-NTU model fluorometer and scattering sensor, which determines the fluorescence and the suspended particle concentration in the water (Sea-Bird Electronics, 2011; Sea-Bird Electronics, n.d.). For the oxygen, chl-a and turbidity data, it was necessary an additional visual quality control procedure in order to manually delete unreliable data, since these values were inconsistent or out of the nominal ranges of measurement of the sensors.

After data processing, a Python code (Van Rossum \& Drake, 2009) was created to obtain the maximum and minimum values of each variable along with the corresponding date and depth, and the results were stored in tables separated by variable (Table 2, Table 3 , Table 4 , Table 5, Table 6, and Table 7). A code was written in MATLAB $^{\circledR}\left(\right.$ MATLAB $\left.^{\circledR}, 2018\right)$ to plot Hovmöller diagrams (Fig. 2, Fig. 3, Fig. 4, Fig. 5, Fig. 6, Fig. 7), which reveal the temporal distribution that each variable presented during the studied interval. Maximum and minimum values in Tables 2 to 7 , retrieved with the Python code, were used to define the respective color scales for each map. A Hovmöller kind diagram was plotted for each of the seven hydrographic stations and six variables, resulting in a total of 42 diagrams.

The annual cycle of the CTD variables were then calculated as the average values for all the stations and depth levels for a particular month. Also, the climate values from a meteorological station located in Santa Elena, La Cruz, Guanacaste (1054'59' N, 85³6'59" W, altitude: 270 masl, Fig. 1, https://www. imn.ac.cr/mapa) were considered to represent the annual cycle of the air surface temperature (maximum, mean, minimum), precipitation, and wind magnitude. The climatology of the sea subsurface temperature in a station located in Salinas Bay $\left(11^{\circ} 01.616^{\prime} \mathrm{N}, 85^{\circ} 45.801^{\prime} \mathrm{W}\right.$, depth: 3.3-4.9 m) described in Alfaro and Cortés (2021) was also included (see Fig. 8a in the next section).

\section{RESULTS}

Temperature: The thermocline is located around $30 \mathrm{~m}$. Vertical temperature distribution has a periodic variability, where cold cycles fit with dry seasons and warm cycles with rainy seasons (Fig. 2). Temperature variability for all stations was similar, but with slight differences, mainly due to depth near the coast. The minimum temperature registered was $15.15{ }^{\circ} \mathrm{C}$ in station I at approximately the maximum depth in February 2011, and the maximum temperature, $29.93{ }^{\circ} \mathrm{C}$, was observed in station IV at 7 $\mathrm{m}$ in June 2009 (Table 2).

Density: Density variability presents the same periodicity as temperature, but with an inverse relation (Fig. 3). Water masses were 

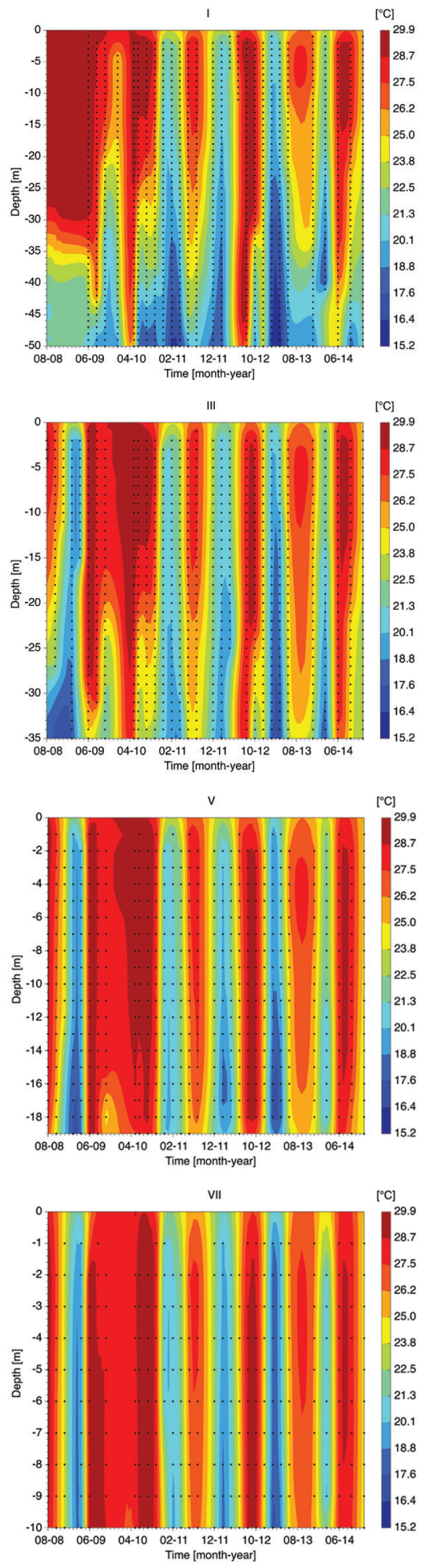
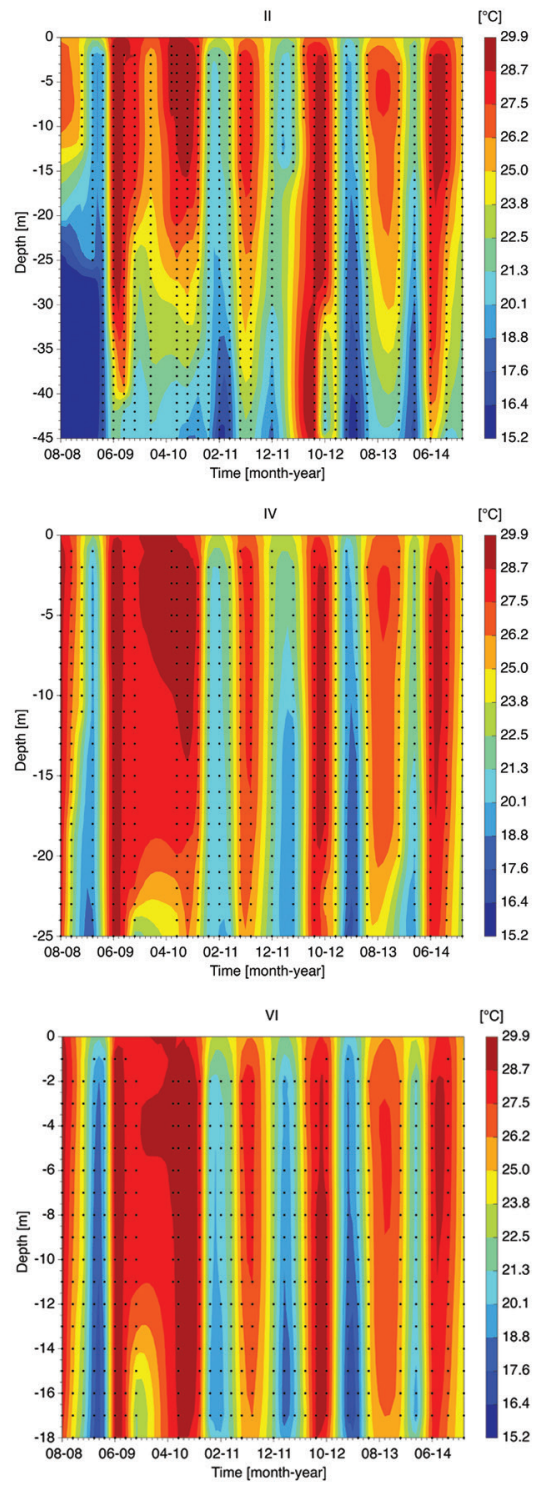

Fig. 2. Temperature vertical distribution at Salinas Bay from August 2008 to December 2014. Stations ordered from the furthest to the closest to the coast: I, II, III, IV, V, VI, VII. Dots in vertical lines correspond to CTD measurements (averaged every meter). 
TABLE 2

Maximum and minimum values of temperature for each station with their respective date and depth

\begin{tabular}{ccccccc}
\hline \multirow{2}{*}{ Station } & \multicolumn{3}{c}{ Maximum } & \multicolumn{3}{c}{ Minimum } \\
\cline { 2 - 7 } & Temperature $\left({ }^{\circ} \mathrm{C}\right)$ & Date & Depth $(\mathrm{m})$ & Temperature $\left({ }^{\circ} \mathrm{C}\right)$ & Date & Depth $(\mathrm{m})$ \\
\hline I & 29.76 & $18 / 6 / 2009$ & -1 & 15.15 & $24 / 2 / 2011$ & -53 \\
II & 29.60 & $18 / 6 / 2009$ & -1 & 15.84 & $24 / 2 / 2011$ & -45 \\
III & 29.35 & $18 / 6 / 2009$ & -1 & 16.50 & $18 / 4 / 2013$ & -37 \\
IV & 29.93 & $18 / 6 / 2009$ & -7 & 17.45 & $13 / 2 / 2013$ & -25 \\
V & 29.49 & $20 / 8 / 2008$ & -1 & 17.21 & $13 / 2 / 2013$ & -18 \\
VI & 29.70 & $18 / 6 / 2009$ & -6 & 17.11 & $13 / 2 / 2013$ & -17 \\
VII & 29.86 & $18 / 6 / 2009$ & -4 & 17.38 & $13 / 2 / 2013$ & -10 \\
\hline
\end{tabular}

TABLE 3

Maximum and minimum values of sigma-t density for each station with their respective date and depth

\begin{tabular}{ccccccc}
\hline \multirow{2}{*}{ Station } & \multicolumn{3}{c}{ Maximum } & \multicolumn{3}{c}{ Minimum } \\
\cline { 2 - 7 } & Density $\left(\mathrm{kg} \mathrm{m}^{-3}\right)$ & Date & Depth $(\mathrm{m})$ & Density $\left(\mathrm{kg} \mathrm{m}^{-3}\right)$ & Date & Depth $(\mathrm{m})$ \\
\hline I & 26.00 & $24 / 2 / 2011$ & -53 & 19.83 & $21 / 10 / 2010$ & -2 \\
II & 25.83 & $18 / 4 / 2013$ & -46 & 19.67 & $23 / 8 / 2012$ & -8 \\
III & 25.64 & $18 / 4 / 2013$ & -37 & 19.73 & $21 / 10 / 2010$ & -2 \\
IV & 25.38 & $13 / 2 / 2013$ & -25 & 19.61 & $21 / 10 / 2010$ & -2 \\
V & 25.56 & $13 / 2 / 2013$ & -18 & 19.67 & $21 / 10 / 2010$ & -1 \\
VI & 25.47 & $13 / 2 / 2013$ & -17 & 19.74 & $21 / 10 / 2010$ & -2 \\
VII & 25.53 & $13 / 2 / 2013$ & -10 & 19.72 & $21 / 10 / 2010$ & -1 \\
\hline
\end{tabular}

TABLE 4

Maximum and minimum values of salinity for each station with their respective date and depth

\begin{tabular}{ccccccc}
\hline \multirow{2}{*}{ Station } & \multicolumn{3}{c}{ Maximum } & \multicolumn{3}{c}{ Minimum } \\
\cline { 2 - 7 } & Salinity (PSU) & Date & Depth $(\mathrm{m})$ & Salinity (PSU) & Date & Depth $(\mathrm{m})$ \\
\hline I & 34.88 & $18 / 4 / 2013$ & -3 & 31.70 & $21 / 10 / 2010$ & -2 \\
II & 35.03 & $13 / 2 / 2013$ & -1 & 31.58 & $21 / 10 / 2010$ & -1 \\
III & 35.15 & $23 / 4 / 2009$ & -2 & 31.59 & $21 / 10 / 2010$ & -2 \\
IV & 34.99 & $13 / 2 / 2013$ & -3 & 31.48 & $21 / 10 / 2010$ & -2 \\
V & 35.56 & $23 / 4 / 2009$ & -2 & 31.53 & $21 / 10 / 2010$ & -1 \\
VI & 35.49 & $23 / 4 / 2009$ & -1 & 31.60 & $21 / 10 / 2010$ & -2 \\
VII & 35.15 & $13 / 2 / 2013$ & -1 & 31.60 & $21 / 10 / 2010$ & -1 \\
\hline
\end{tabular}

denser during upwelling events and at greater depths. Less dense water is observed mostly at shallow layers and during the rainy season. Sigma-t density ranged from $19.61 \mathrm{~kg} \mathrm{~m}^{-3}$, in station IV at $2 \mathrm{~m}$ in October 2010 , to $26.00 \mathrm{~kg}$ $\mathrm{m}^{-3}$, in station I at approximately the maximum depth in February 2011 (Table 3).

Salinity: Salinity had a seasonal variability with higher values found in the dry season (December-April) and lower during the rainy months (May-November). The variation in salinity was observed mainly within the first $25 \mathrm{~m}$ and at deeper layers tended to be stable (Fig. 4). Salinity ranged from 31.48 PSU in station IV at $2 \mathrm{~m}$ in October 2010, to 35.56 PSU in station V at $2 \mathrm{~m}$ in April 2009 (Table $4)$. Throughout the entire time series, salinity at depths of $25 \mathrm{~m}$ and below was higher than 34 PSU, except between April and December 2012, when a warm episode took place.

Oxygen: Dissolved oxygen had higher values within the first $30 \mathrm{~m}$ depth with 

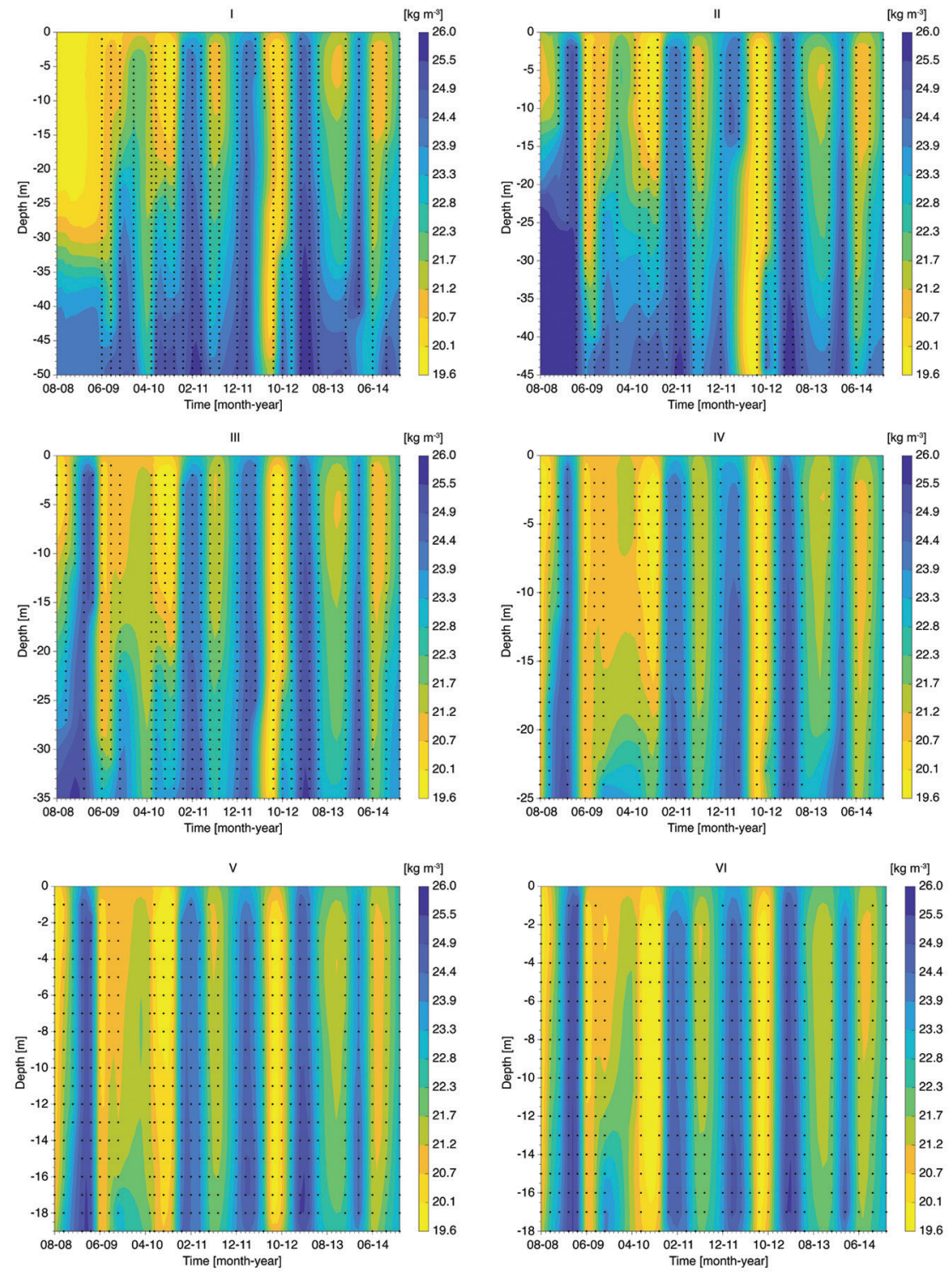

$[$ [kg ms]
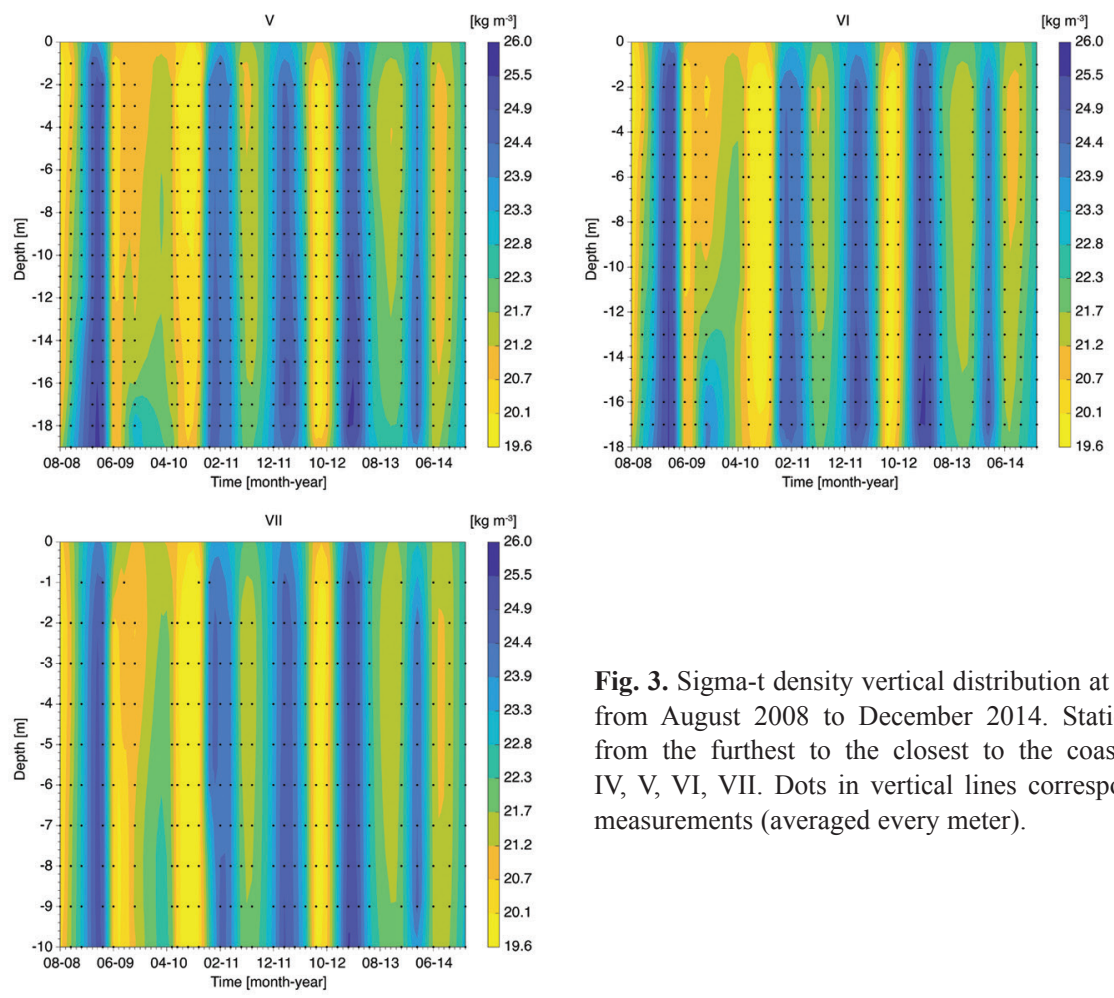

Fig. 3. Sigma-t density vertical distribution at Salinas Bay from August 2008 to December 2014. Stations ordered from the furthest to the closest to the coast: I, II, III, IV, V, VI, VII. Dots in vertical lines correspond to CTD measurements (averaged every meter). 

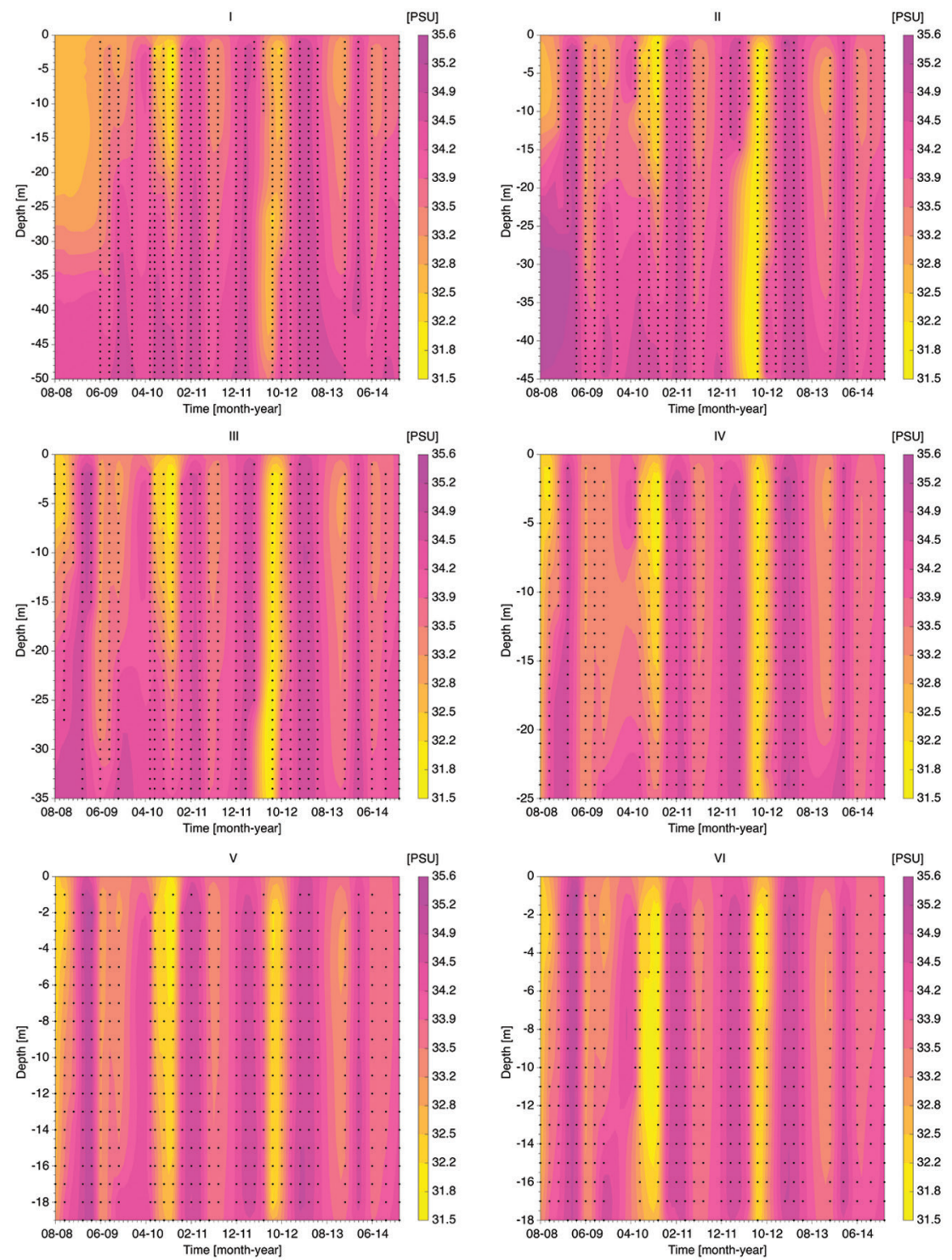

VII
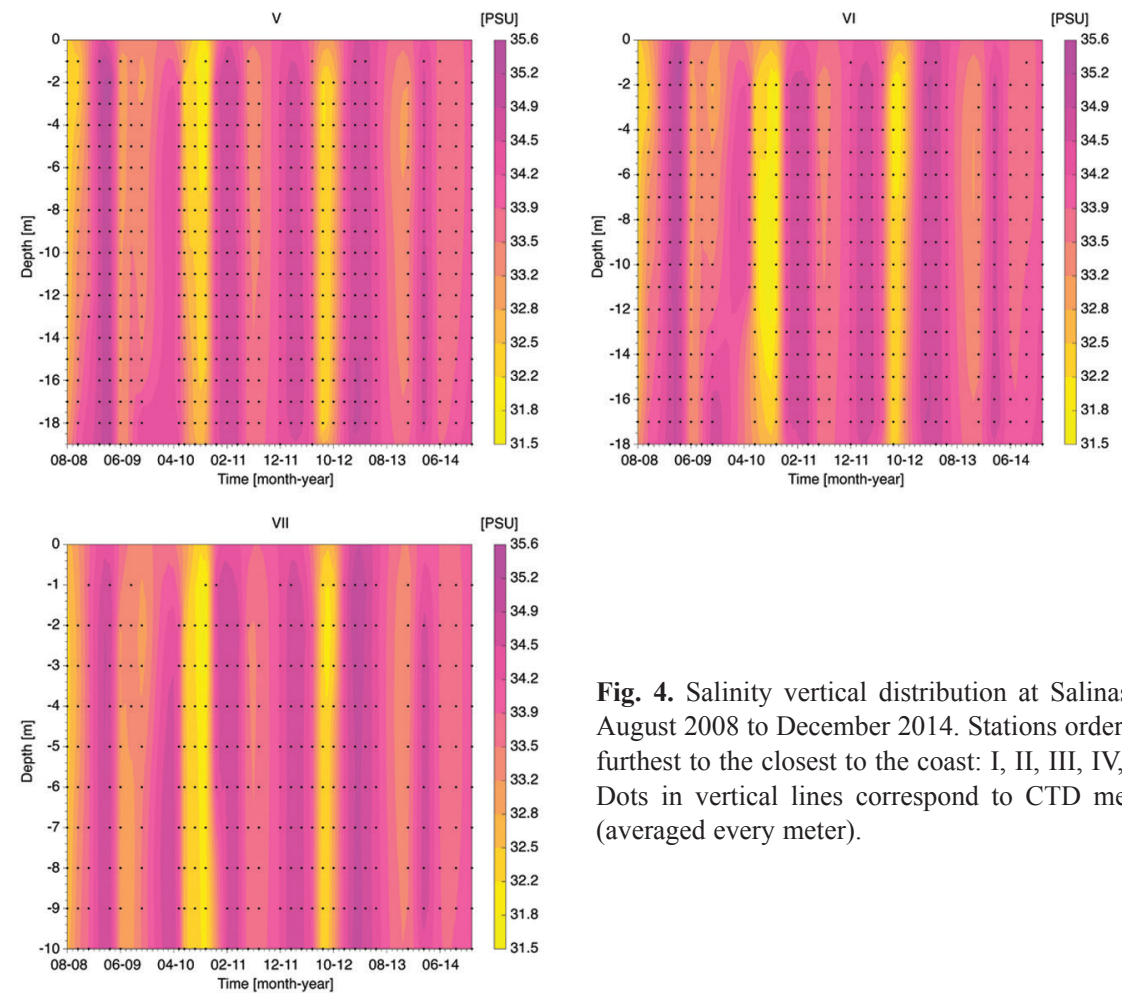

Fig. 4. Salinity vertical distribution at Salinas Bay from August 2008 to December 2014. Stations ordered from the furthest to the closest to the coast: I, II, III, IV, V, VI, VII. Dots in vertical lines correspond to CTD measurements (averaged every meter). 

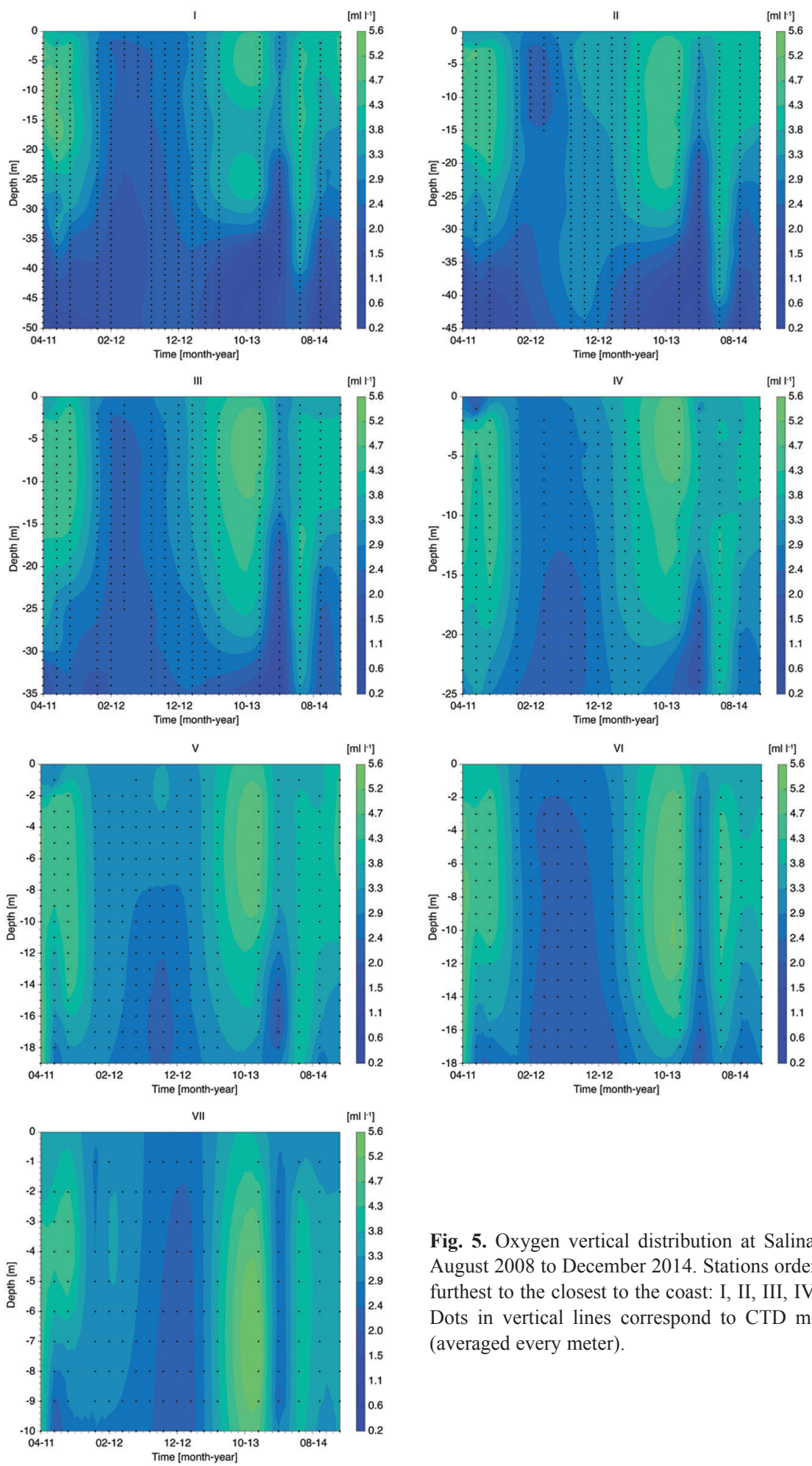

Fig. 5. Oxygen vertical distribution at Salinas Bay from August 2008 to December 2014. Stations ordered from the furthest to the closest to the coast: I, II, III, IV, V, VI, VII. Dots in vertical lines correspond to CTD measurements (averaged every meter). 
TABLE 5

Maximum and minimum values of oxygen for each station with their respective date and depth

\begin{tabular}{ccccccc}
\hline \multirow{2}{*}{ Station } & \multicolumn{3}{c}{ Maximum } & \multicolumn{3}{c}{ Minimum } \\
\cline { 2 - 7 } & Oxygen $\left(\mathrm{ml} \mathrm{l}^{-1}\right)$ & Date & Depth $(\mathrm{m})$ & Oxygen $\left(\mathrm{ml} \mathrm{l}^{-1}\right)$ & Date & Depth $(\mathrm{m})$ \\
\hline I & 4.88 & $23 / 6 / 2011$ & -16 & 0.17 & $14 / 4 / 2011$ & -53 \\
II & 4.82 & $23 / 6 / 2011$ & -3 & 0.30 & $14 / 4 / 2011$ & -47 \\
III & 4.91 & $5 / 12 / 2013$ & -3 & 0.64 & $20 / 3 / 2014$ & -36 \\
IV & 5.02 & $5 / 12 / 2013$ & -1 & 1.81 & $20 / 3 / 2014$ & -24 \\
V & 5.10 & $14 / 4 / 2011$ & -15 & 1.78 & $20 / 3 / 2014$ & -17 \\
VI & 5.12 & $14 / 4 / 2011$ & -8 & 1.89 & $20 / 3 / 2014$ & -17 \\
VII & 5.61 & $5 / 12 / 2013$ & -8 & 2.13 & $23 / 6 / 2011$ & -10 \\
\hline
\end{tabular}

TABLE 6

Maximum and minimum values of chl-a for each station with their respective date and depth

\begin{tabular}{ccccccc}
\hline \multirow{2}{*}{ Station } & \multicolumn{3}{c}{ Maximum } & \multicolumn{3}{c}{ Minimum } \\
\cline { 2 - 7 } & chl-a $\left(\mathrm{mg} \mathrm{m}^{-3}\right)$ & Date & Depth $(\mathrm{m})$ & chl-a $\left(\mathrm{mg} \mathrm{m}^{-3}\right)$ & Date & Depth $(\mathrm{m})$ \\
\hline I & 4.57 & $4 / 12 / 2014$ & -6 & 0.01 & $13 / 6 / 2013$ & -44 \\
II & 4.88 & $4 / 12 / 2014$ & -7 & 0.01 & $23 / 8 / 2012$ & -3 \\
III & 5.06 & $4 / 12 / 2014$ & -6 & 0.02 & $18 / 8 / 2011$ & -3 \\
IV & 4.24 & $4 / 12 / 2014$ & -6 & 0.03 & $23 / 8 / 2012$ & -4 \\
V & 4.79 & $4 / 12 / 2014$ & -7 & 0.05 & $18 / 8 / 2011$ & -4 \\
VI & 4.84 & $4 / 12 / 2014$ & -7 & 0.07 & $13 / 2 / 2013$ & -17 \\
VII & 4.04 & $4 / 12 / 2014$ & -5 & 0.02 & $23 / 8 / 2012$ & -1 \\
\hline
\end{tabular}

concentrations around 3-5 $\mathrm{ml} \mathrm{l}^{-1}$ (Fig. 5). Annual variability associated with the upwelling was not so clear for oxygen, however, the tendency was for higher concentrations of dissolved oxygen during the rainy season when compared with the dry season. The lowest value for dissolved oxygen was $0.17 \mathrm{ml}$ $\mathrm{I}^{-1}$ in station I at approximately the maximum depth in April 2011, and the highest was 5.61 $\mathrm{ml} \mathrm{l}^{-1}$ in station VII at $8 \mathrm{~m}$ in December 2013 (Table 5). Oxygen did not show a strong seasonal variability and therefore the interannual signal dominated.

Chl-a: High concentrations of chl-a were predominant in the first $25 \mathrm{~m}$ and when the upwelling was active (Fig. 6). Maximum chl-a concentration, of $5.06 \mathrm{mg} \mathrm{m}^{-3}$ was found in station III at $6 \mathrm{~m}$ in December 2014, during an upwelling event. On the other hand, chl-a minimum took place in station I at $44 \mathrm{~m}$, during rainy season in June 2013 (Table 6). The interannual signal was predominant for chl-a dynamics, as a consequence of the weak seasonal variability.

Turbidity: Turbidity did not have an evident periodic tendency associated with upwelling, as is the case for other parameters, but there were areas with higher turbidity, mainly at the bottom of different stations during rainy season (Fig. 7). Turbidity values ranged from 0.0184 NTU in station I at approximately the maximum depth in April 2011, to 3.6706 NTU in station VII at $9 \mathrm{~m}$ in June 2011 (Table 7). Turbidity dynamics depended mainly on the interannual signal, since its seasonal variability was also weak.

Annual Cycle: Figure 8 shows the monthly mean values of the CTD variables described above, plus the air surface temperature (maximum, mean, minimum), precipitation, wind magnitude and sea subsurface temperature. Sea subsurface temperature minimum was observed in February-March, with a relative minimum in 

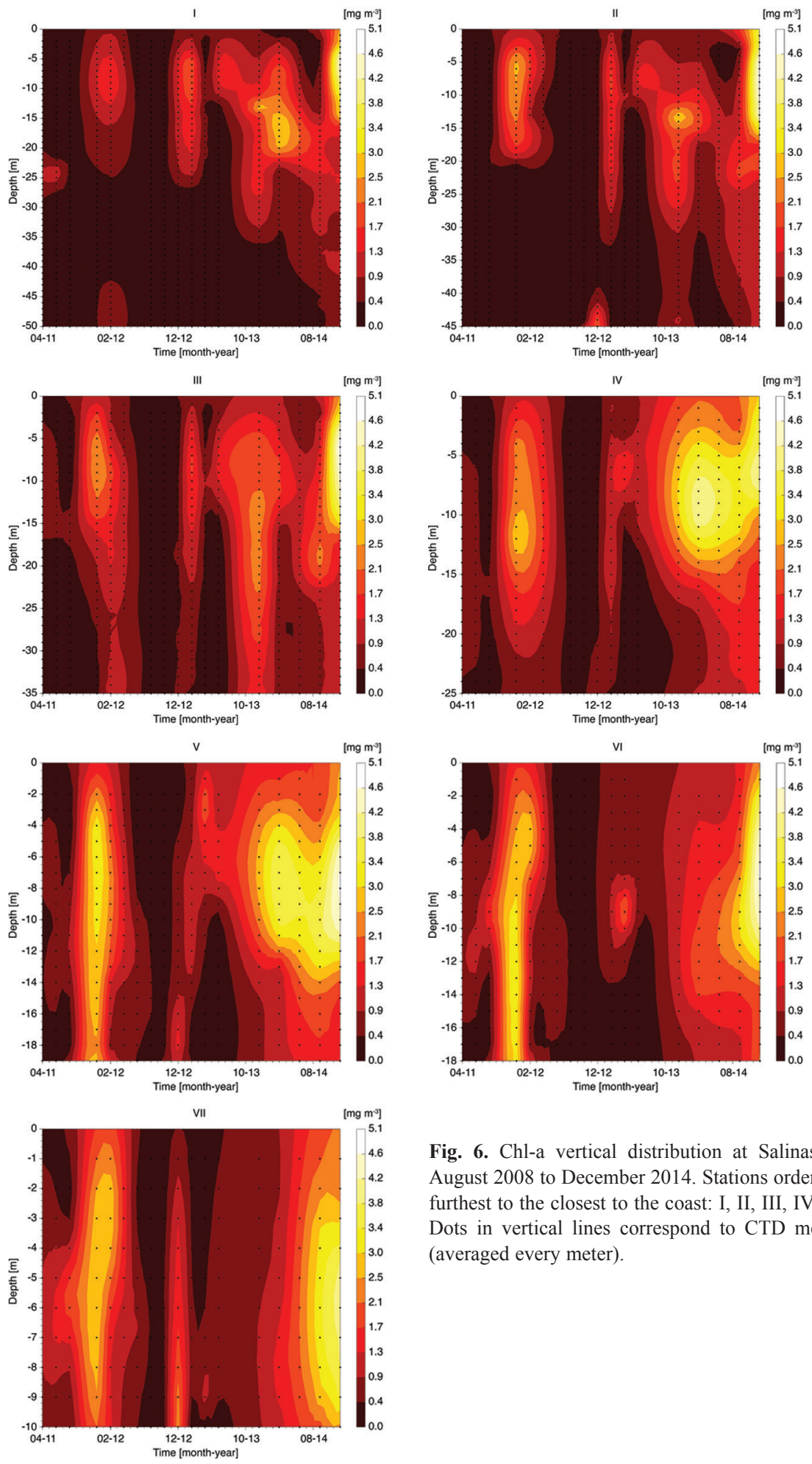

Fig. 6. Chl-a vertical distribution at Salinas Bay from August 2008 to December 2014. Stations ordered from the furthest to the closest to the coast: I, II, III, IV, V, VI, VII. Dots in vertical lines correspond to CTD measurements (averaged every meter). 

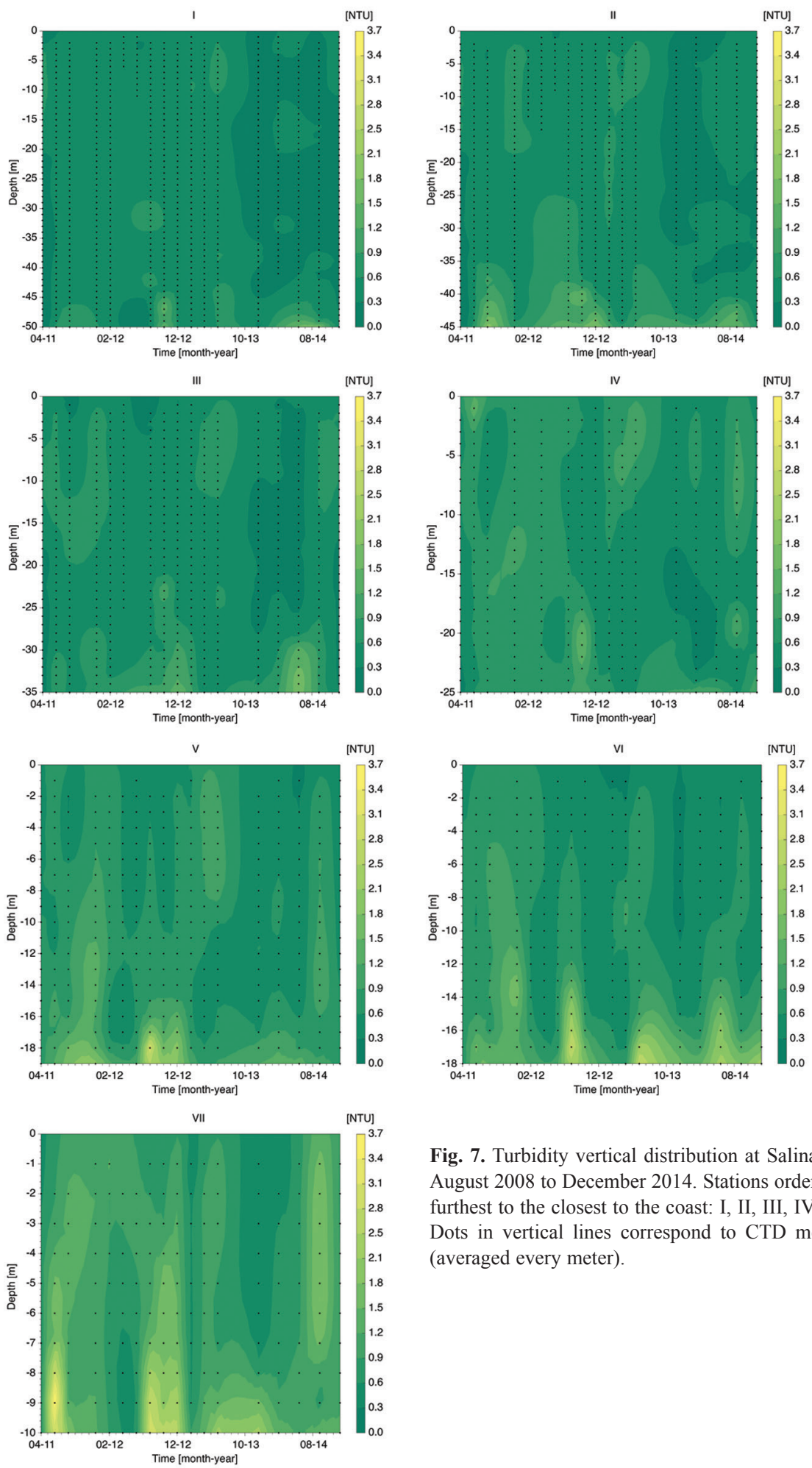

Fig. 7. Turbidity vertical distribution at Salinas Bay from August 2008 to December 2014. Stations ordered from the furthest to the closest to the coast: I, II, III, IV, V, VI, VII. Dots in vertical lines correspond to CTD measurements (averaged every meter). 
TABLE 7

Maximum and minimum values of turbidity for each station with their respective date and depth

\begin{tabular}{ccccccc}
\hline \multirow{2}{*}{ Station } & \multicolumn{3}{c}{ Maximum } & \multicolumn{3}{c}{ Minimum } \\
\cline { 2 - 7 } & Turbidity (NTU) & Date & Depth $(\mathrm{m})$ & Turbidity (NTU) & Date & Depth (m) \\
\hline I & 3.13 & $18 / 9 / 2014$ & -53 & 0.02 & $14 / 4 / 2011$ & -52 \\
II & 2.45 & $5 / 12 / 2012$ & -46 & 0.04 & $14 / 4 / 2011$ & -36 \\
III & 1.89 & $5 / 12 / 2012$ & -37 & 0.04 & $14 / 4 / 2011$ & -34 \\
IV & 1.87 & $4 / 12 / 2014$ & -27 & 0.09 & $14 / 4 / 2011$ & -26 \\
V & 3.02 & $23 / 8 / 2012$ & -18 & 0.17 & $12 / 6 / 2014$ & -1 \\
VI & 2.87 & $23 / 8 / 2012$ & -17 & 0.21 & $13 / 2 / 2013$ & -1 \\
VII & 3.67 & $23 / 6 / 2011$ & -9 & 0.35 & $13 / 2 / 2013$ & -1 \\
\hline
\end{tabular}

A

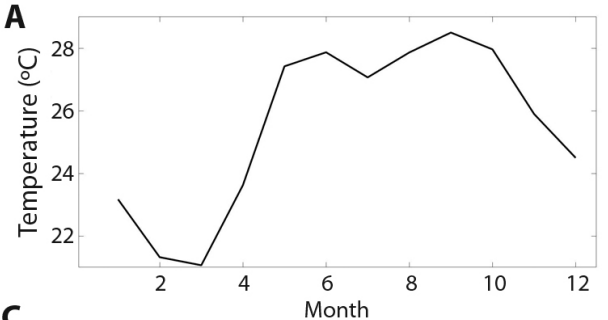

C

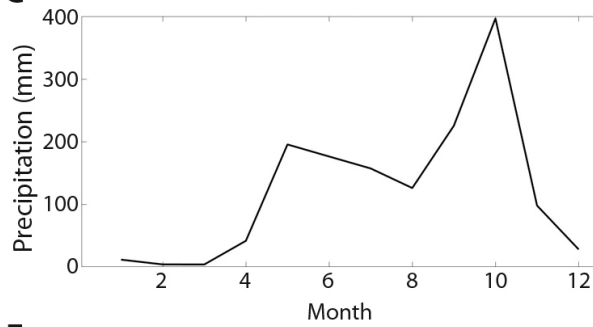

E

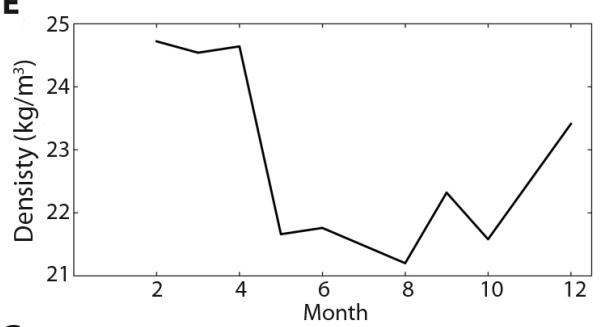

G

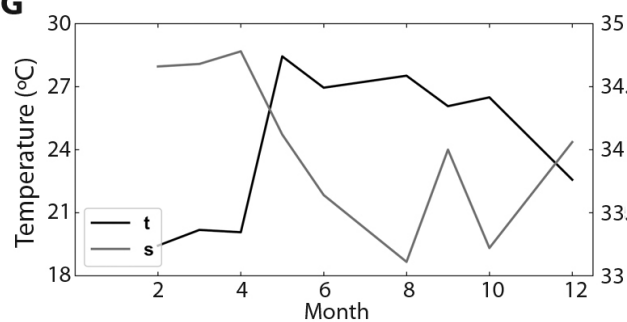

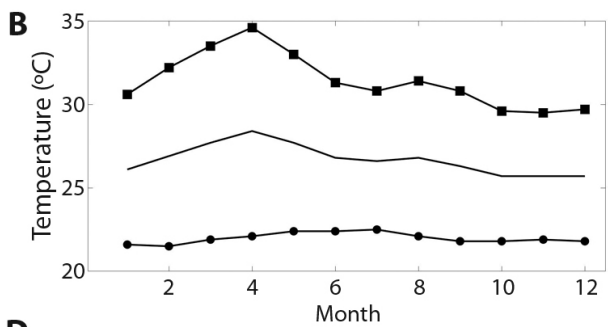

D
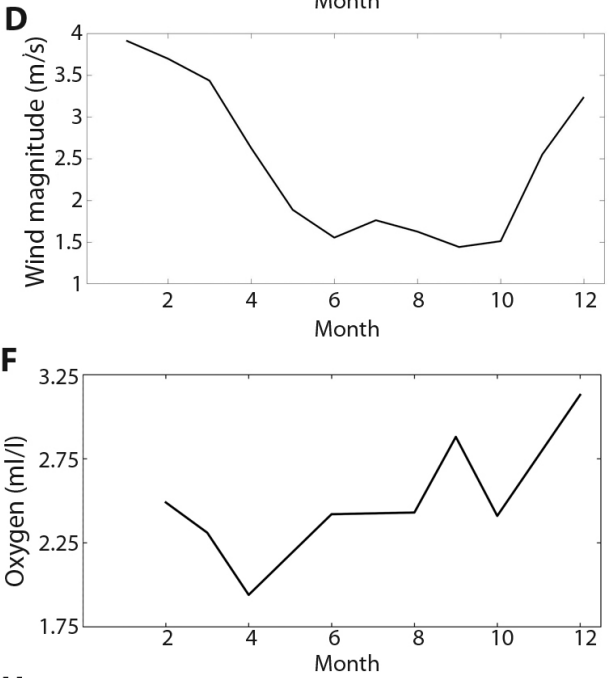

H

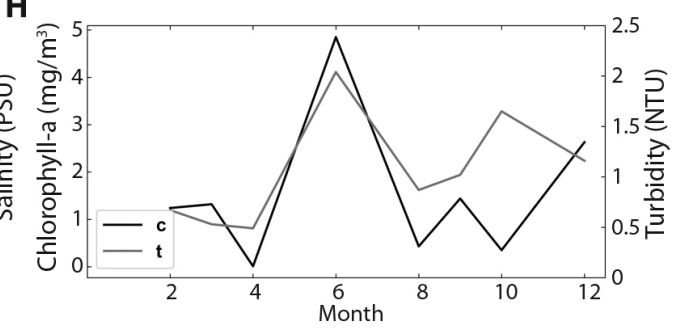

Fig. 8. Annual cycle of the: a) sea subsurface temperature in a station in Salinas Bay $\left(11^{\circ} 01.616^{\prime} \mathrm{N}, 85^{\circ} 45.801^{\prime} \mathrm{W}\right.$, depth: 3.3-4.9m), b) air surface temperature (maximum-squares, average-solid and minimum-dots), c) precipitation, d) wind magnitude, in Santa Elena, La Cruz, Guanacaste meteorological station (10 54' 59” N, 85 36' 59" W, altitude: 270 masl), and e) density, f) oxygen, g) temperature and salinity, and h) chl-a and turbidity, for the CTD stations in Salinas Bay showed in Figure 1. 
July between the two maxima of May-June and September-October (Fig. 8a). Maximum and minimum air temperature presented their lowest values in October-November and JanuaryFebruary and the highest in March-April and July, respectively. Mean air temperature is a combination of the maximum and minimum annual cycles, with maximum and minimum in April and the quarter of October-NovemberDecember (Fig. 8b). Precipitation presented a typical bimodal distribution of the Central American Pacific slope, with a dry season in December-April and a rainy season with two maxima in May-June and September-October, with a reduction in July-August associated with the Mid-Summer Drought (Fig. 8c). Wind magnitude presented high values for the boreal winter, from December to March and low values in June, September and October. A relative maximum is observed for July (Fig. $8 \mathrm{~d})$. The annual cycle of the temperature and salinity from the CTD casts tend to covariate in opposite way. From December to April, high (low) salinity (temperature) values were observed, meanwhile from May to October respectively, high (low) temperature (salinity) values were reported (Fig. 8g). Density annual cycle responds to the salinity and temperature ones, with high values from December to April and low values from May to October (Fig. 8e). Oxygen, chl-a and turbidity were minimum in April. Chl-a and turbidity presented a peak in June and the oxygen in December (Fig. 8f, Fig. 8g, Fig. 8h).

\section{DISCUSSION}

Temperature: Absolute maximum temperature was observed within shallow waters at $7 \mathrm{~m}$, as is expected for warmer water masses. Maximum for all stations, except for $\mathrm{V}$, occurred in June 2009, which is in accordance with a warm event recorded by Alfaro et al. (2012) at Culebra Bay, where a SST standardized anomaly of $0.64{ }^{\circ} \mathrm{C}$ was observed. June corresponds to the rainy season when SSTs in the ETP are expected to be warmer and the upwelling is not active. According to the Costa
Rican National Meteorological Institute (IMN in Spanish) weather bulletin, during June 2009 warm event atmospheric mean temperatures and maximum absolute temperatures in the Pacific region were higher than the historic mean (Quirós, 2009). Maximum for station V occurred in August 2008, under the influence of a persistent warming of the SSTs in the equatorial ETP, and a positive anomaly of temperature offshore Costa Rican North Pacific coast, according to IMN bulletin (Sánchez, 2008). Minimum absolute and for stations I-II was observed during a cold event in February 2011, associated with a cold front and a high-pressure system, which accelerated winds speed and favored upwelling (Morera, 2011). Minimum for station III took place in April 2013, a month characterized by pressure anomalies due to polar air masses and cold fronts that increased winds intensity (Chinchilla, 2013). Minimum for stations IV to VII was observed in February 2013, under dry conditions, the incidence of cold fronts and the predominance of strong northeast winds (Morera, 2013b). The Oceanic Niño Index (ONI) 3-month running mean (3-MRM) anomalous SST for periods that include the observation of the absolute maximum temperature and of the maxima temperatures at all stations (except V) were neutral for April-May-June and May-June-July but warm for June-July-August period (0.5 ${ }^{\circ} \mathrm{C}$ 3-MRM). The ONI values for all periods that include the maximum of station $\mathrm{V}$ were neutral. The absolute maximum and stations I and II maxima were observed during cold events in accordance with the ONI index $(-1.4$ ${ }^{\circ} \mathrm{C}$ for December-January-February, $-1.2{ }^{\circ} \mathrm{C}$ for January-February-March and $-0.9^{\circ} \mathrm{C}$ for February-March -April). ONI values were neutral for all the periods that cover the observation of the minima at stations III to VII (Climate Prediction Center, n.d.).

Density: Absolute maximum density was observed at Station I at approximately the maximum depth, during a cold event caused by a high-pressure in February 2011 (Morera, 2011), when temperature minima was observed. 
Stations II and III registered the maximum in April 2013, influenced by pressure anomalies due to polar air masses and cold fronts which increased winds intensity (Chinchilla, 2013). Maximum for stations IV-VII occurred in February 2013 , with dry conditions, the incidence of cold fronts and the predominance of strong northeast winds (Morera, 2013b). Absolute minimum in October 2010 is associated with shallow depths as it was found at $2 \mathrm{~m}$ in station $\mathrm{IV}$, during the wet season when upwelling is not present or is very weak. It should be noted that according to Figure 8c, September and October are the rainiest months in the region. Besides, atmospheric temperature maxima were higher than the historic mean (Solano, 2010). In general, heat flux at ETP tends to be lower during the wet season since the presence of the cloud tops caused by the displacement of the Inter-Tropical Convergence Zone reduces solar radiation incidence over sea surface (Amador, Rivera, et al., 2016). Nevertheless, during the rainy season SSTs at Salinas Bay are warmer given that the upwelling is inactive, resulting in lower water densities locally. The other stations registered density minimum the same day that station IV at a depth between 1-2 m, with the exception of station II where density minimum was observed in August 2012 at $8 \mathrm{~m}$. This condition could be related to a warming event, which started in April-May and peaked in June-July, due to the increase in the air temperatures and SST (Poleo \& Stolz, 2012a). In addition, the North Pacific of Costa Rica presented a positive precipitation anomaly, rain was greater than normal, and trade winds weakened in August as a result of the weakening of the North Atlantic Anticyclone, resulting in unfavorable conditions for an upwelling as is expected during the rainy season (Poleo \& Stolz, 2012b).

Salinity: Higher salinities were observed during upwelling events, associated with colder and denser waters. Absolute maximum was located in station $\mathrm{V}$ in shallow waters $(2 \mathrm{~m})$, and is related to a high-pressure system, which caused a cold front that accelerated trade winds in April 2009, favoring the upwelling, which is also the case for stations III and VI maximum (Alfaro, 2009). Maximum for station I occurred in April 2013, under the influence of pressure anomalies due to polar air masses and cold fronts that strengthened trade winds (Chinchilla, 2013). Maximum for stations II, IV, and VII happened in February 2013, a month characterized by dry conditions, the incidence of cold fronts and the predominance of strong northeast winds (Morera, 2013b). Minima for all stations were observed in October 2010, during the wet season, as in the case of density. The observed seasonal dynamics for salinity is consistent with observations made in the Gulf of Papagayo, where lower salinity concentrations during the rainy season are associated with increased rainfall (Loza-Álvarez et al., 2018).

Oxygen: Absolute maximum oxygen concentrations were observed at $8 \mathrm{~m}$, only a few meters above the maximum chlorophyll layer, in December 2013, a month characterized by strong trade winds (Morera, 2013a). Stations III-IV and VII maxima coincide temporally with absolute maximum. In the case of stations I-II, maximum occurred in June 2011, under fast winds on the Pacific coast and short periods with dry conditions (Morera \& Stolz, 2011). For stations V-VI the maximum was observed in April 2011, a windy month with dry conditions, influenced by cold fronts (Chinchilla, 2011a). Absolute minimum was registered in April 2011, but it is related to a high depth reached at station I rather than synoptic conditions, since oxygen constantly decreases with depth. The above applied for station II, where the minimum was observed at approximately the maximum depth the same date. In stations III-VI the minimum was located near the bottom in March 2014, a dry month with high pressures and persistent trade winds (Solano, 2014). Minimum for station VII was also located near the seabed, in June 2011 during wet season, whereby it is more related to depth than to weather conditions. 
Chl-a: Absolute maxima of chl-a were recorded in December 2014, a month when four cold fronts, which generated strong trade winds and wind gust speed over $100 \mathrm{~km} \mathrm{~h}^{-1}$, were observed locally (Chinchilla, 2014). However, this event was aborted by an easterly wind burst in the western Pacific, which led to an event of El Niño (Levine \& McPhaden, 2016). Maxima for all stations was registered in the same date. Chl-a concentrations tend to increase during upwelling, associated with an increase in biological productivity, and are higher in the thermocline. Absolute minimum was observed in station I, within deep waters, at $44 \mathrm{~m}$ in June 2013, under typical wet season conditions (Poleo \& Stolz, 2013). In the case of stations II, IV and VII, the minimum was observed in August 2012, a month characterized by weak trade winds, a rainy pattern above the historic records for the North Pacific and atmospheric temperatures warmer than the historic mean associated with an El Niño (Poleo \& Stolz, 2012b). Minimum for stations III and V occurred in August 2011, with the incidence of wet conditions due to wind from the west, which fostered rainy activity in Guanacaste (Chinchilla, 2011b). Station VI minimum was observed in February 2013 under dry conditions (Morera, 2013b), whereby it is associated with depth $(17 \mathrm{~m})$ rather than synoptic conditions.

Turbidity: In some stations a periodicity in turbidity was observed, with remarkable increases close to the seabed during wet seasons. Absolute maximum was registered in station VII in June 2011, during a short dry period within the rainy season, with above normal wind speed in the Pacific, weak trade winds and atmospheric temperatures above the historic mean (Morera \& Stolz, 2011). At station I the maximum occurred in September 2014, when trade winds weakened in Guanacaste favoring an increase in humidity, and low-pressure systems resulted in extreme events, particularly on September 13 and 18 (sampling day), fostering intense precipitations in the region (Poleo \& Stolz, 2014). In addition, during that month the influence of El Niño affected the weather in the region (Alvarado, 2014b). For station IIIII, the maximum appeared in December 2012, with predominance of trade winds and less cold fronts than usual (Solano, 2012). For station IV the maximum was registered in December 2014, a month characterized by indirect incidence of cold fronts and strong trade winds, particularly during an important event the first ten days, which was present when the sampling was carried out on the fourth day (Chinchilla, 2014). Also, El Niño was active during December 2014 after intensifying in previous months (Alvarado, 2014a). The maximum in stations V-VI happened in August 2012, with the presence of El Niño, weak trade winds and positive anomalies of atmospheric temperatures and precipitation (Poleo \& Stolz, 2012b). Absolute minimum was found in April 2011, in the presence of a cold front, which caused moderate wind (Chinchilla, 2011a). Minimum for stations I-IV occurred the same month. For station $\mathrm{V}$ the minimum was recorded in June 2014, when the North Pacific was experiencing a drought associated with El Niño (Naranjo, 2014). The minimum for stations VI and VII occurred in February 2013, a month affected by windy conditions due to cold fronts (Morera, 2013b). The heterogeneity of atmospheric conditions at the moment when maxima or minima values were presented does not allow to conclude a relation between turbidity, synoptic conditions and the upwelling, since the values do not have a seasonal periodicity. Most maxima values were observed when an event of El Niño was active, which could indicate a relation between them; however, a minimum was also registered during an El Niño event. All of the maxima were located at the seabed of their respective stations. In the case of the minima, only those presented in April 2011 are located in the bottom of the stations, and turbidity levels remained low within the entire water column.

Annual Cycle relationships: Density annual cycle presented high values from December to April, in agreement with the dry 
season in the Central American Pacific slope and with the months in which the magnitude of the wind is also high (Amador et al. 2006). This season is associated with high incoming solar radiation, important evaporation, low cloudiness, sea water transport offshore, minimum runoff and a deeper mixing layer (Amador, Durán-Quesada, et al., 2016; Durán-Quesada et al., 2020). During December-April, density is consequently associated with high salinity values and low sea temperatures of the water column in Salinas Bay. Oxygen, chl-a and turbidity were minimum in April, in which the air surface temperature was maximum. From May to October occurs the rainy season, increasing the runoff-freshwater input to the bay and the cloud cover. Additionally, the wind magnitude decreases along with the evaporation, the sea water transport offshore and the depth of the mixing layer. These factors increased the Salinas Bay sea water temperature and reduce its salinity. Oxygen presented a positive trend from the begin to the end of the rainy season, when the wind magnitude and the air surface temperature presented negative trends. Chl-a and turbidity presented a peak in June, in agreement with the first part of the rainy season. Turbidity also presented a relative maximum in October. These turbidity peaks could be related with the sediment runoff transport during the peaks of the rainy season. June chl-a peak could be associated with the high incoming solar radiation and low wind magnitude values observed during the mornings of the rainy season (Alfaro et al., 2012), but the relative maximum in December could be associated with a decrease in the cloud coverture (Amador et al., 2006).

\section{Conclusions}

Our results in Salinas Bay, should be interpreted in the context of the Eastern Tropical Pacific seasonal and interannual variability described in detail by previous works of Amador et al. (2006); Amador, Durán-Quesada, et al. (2016), Amador, Rivera, et al., (2016) and Durán-Quesada et al. (2020). The spatial and temporal dynamics of the hydrology in Salinas Bay was influenced by the coastal upwelling events, as its effects include lower SSTs, higher salinity and density, and the movement of dissolved inorganic nutrients toward the surface, leading to favorable conditions for biological blooming and increasing chlorophyll-a concentrations, as it was observed in February 2013. The periodicity of oxygen, chl-a, and turbidity is not as remarkable as with the other variables, but it can be associated with the seasons. The climatic conditions influenced the appearance of maximum and minimum values for the variables. For example, rainy patterns above the historic records, as the June 2013, could be associated with observed minima of chl-a in some stations. The region also presented an interannual variability, such as that associated with ENSO, which can counteract the upwelling during warm events such as the identified cases of August 2008 and June 2009.

Cold fronts and high-pressure anomalies associated with polar air masses are the main synoptic conditions related to temperature and turbidity minima (except in station V) and density, salinity and chl-a maxima, given that these conditions strengthen the winds that favor the upwelling in the studied region. Moreover, atmospheric and sea surface positive temperature anomalies, positive precipitation anomalies, weak trade winds and the influence of El Niño are the principal meteorological conditions for temperature and most of turbidity maxima and density, salinity, and chl-a minima (except in station VI). Turbidity maxima at stations II, III and IV were recorded under strong trade winds but with a lower incidence of cold fronts and, in the case of station IV maximum, during an event of El Niño. As a result, seasonal and interannual variability can counteract their effects on the oceanographic parameters when they temporally coincide. Both oxygen maximum and minimum were measured during the upwelling but, oxygen minima were related to depth rather than synoptic conditions.

Annual and interannual variation observed in Salinas bay influences the local ecosystem and that is reflected in the growth of algae 
(e.g., Sargassum), as reported by Cortés et al. (2014). According to Morales-Ramírez, TillPons, Alfaro, Corrales-Ugalde, \& SheridanRodríguez. (2021), zooplankton in Salinas Bay responds in accordance with changes in the structure of the oceanographic conditions modulated through the seasonal upwelling in the region. Compared to other coastal areas in the Costa Rican North Pacific, Salinas Bay seems to be a healthy local ecosystem.

Ethical statement: authors declare that they all agree with this publication and made significant contributions; that there is no conflict of interest of any kind; and that we followed all pertinent ethical and legal procedures and requirements. All financial sources are fully and clearly stated in the acknowledgements section. A signed document has been filed in the journal archives.

\section{ACKNOWLEDGMENTS}

This project was initially supported by the Vicerrectoría de Investigación of the Universidad de Costa Rica (project A5037), and later partly support by UCR projects: B8766, B9454, EC497and C0610. AR thanks the BSc Physics Program at the UCR, for its support in the FS0624 course. To Paula M. Pérez Briceño for her assistance with Figure 1.

\section{RESUMEN}

\section{Dinámica espacial y temporal de la hidrología en Bahía Salinas, Costa Rica, Pacífico Tropical Oriental}

Introducción: Bahía Salinas se encuentra embebida en la piscina de agua cálida del Pacífico Tropical Oriental (PTO) o del Este (PTE), caracterizada por aguas superficiales cálidas, poco salinas, una termoclina fuerte y poco profunda y una importante diversidad biológica. La productividad primaria de la región está influenciada por el afloramiento oceánico, el cual se presenta durante el invierno boreal como resultado del fortalecimiento de los vientos alisios.

Objetivo: Estudiar la dinámica espacial y temporal de parámetros físico-químicos en siete estaciones hidrográficas en Bahía Salinas, Costa Rica, a través del análisis de datos de CTD; y relacionar los eventos cálidos y fríos con las condiciones atmosféricas presentes al medir los datos.
Métodos: Se muestrearon y seleccionaron siete estaciones hidrográficas en Bahía Salinas entre agosto de 2008 y diciembre de 2014. Las variables procesadas para su análisis son temperatura, densidad, salinidad, oxígeno, clorofilaa y turbidez. Una vez procesados los datos se graficaron 42 diagramas tipo Hovmöller.

Resultados: Todas las variables, excepto la turbidez, presentaron una periodicidad estacional asociada al afloramiento. En general, se observaron aguas más frías y densas, mayores concentraciones de salinidad y clorofila-a y valores menores de oxígeno disuelto durante la estación seca, cuando el afloramiento estaba activo. Por el contrario, durante la estación lluviosa las masas de agua eran más cálidas y menos densas, las concentraciones de salinidad y clorofila-a disminuyeron y los valores de oxígeno disuelto tendieron a aumentar.

Conclusiones: La dinámica espacial y temporal de la hidrología en Bahía Salinas fue influenciada por los eventos de afloramiento costero. La región también presentó una variabilidad interanual, como la asociada con el ENOS. La variabilidad estacional y la interanual pueden contrarrestar sus efectos sobre los parámetros oceanográficos cuando coinciden temporalmente.

Palabras clave: afloramiento; chorros transístmicos; CTD; Papagayo; condiciones sinópticas.

\section{REFERENCES}

Alexander, M. A., Seo, H., Xie, S. P., \& Scott, J. D. (2012). ENSO's impact on the gap wind regions of the eastern tropical Pacific Ocean. Journal of Climate, 25(10), 3549-3565. https://doi.org/10.1175/ JCLI-D-11-00320.1

Alfaro, E. J., \& Cortés, J. (2021). Forcing of cool and warm subsurface water events in Bahía Salinas, Costa Rica. Revista de Biología Tropical, 69(Supplement 2), S127-S141.

Alfaro, E. J., \& Cortés, J. (2012). Atmospheric forcing of cool subsurface water events in Bahía Culebra, Gulf of Papagayo, Costa Rica. Revista de Biología Tropical, 60(Supplement 2), S173-S186. https://doi. org/10.15517/rbt.v60i2.20001

Alfaro, E. J., Cortés, J., Alvarado, J. J., Jiménez, C., León, A., Sánchez-Noguera, C., . . . Ruiz, E. (2012). Clima y temperatura sub-superficial del mar en Bahía Culebra, Golfo de Papagayo, Costa Rica. Revista de Biología Tropical, 60(Supplement 2), S159-S171. https://oi.org/10.15517/rbt.v60i2.20000

Alfaro, E., \& Lizano, O. G. (2001). Algunas relaciones entre las zonas de surgencia del Pacífico Centroamericano y los Océanos Pacífico y Atlántico Tropical. Revista de Biología Tropical, 49(Supplement 2), S185-S193. 
Alfaro, R. (2009). Boletín meteorológico abril de 2009. Boletín Meteorológico Mensual. Instituto Meteorológico de Costa Rica, San José, Costa Rica. https:// www.imn.ac.cr/boletin-meteorologico

Alvarado, L. F. (2014a). Estado del fenómeno ENOS, diciembre. Boletín Meteorológico Mensual. Instituto Meteorológico de Costa Rica, San José, Costa Rica. https://www.imn.ac.cr/boletin-meteorologico

Alvarado, L. F. (2014b). Estado del fenómeno ENOS, setiembre. Boletín Meteorológico Mensual. Instituto Meteorológico de Costa Rica, San José, Costa Rica. https://www.imn.ac.cr/boletin-meteorologico

Amador, J. A., Alfaro, E. J., Lizano, O. G., \& Magaña, V. O. (2006). Atmospheric forcing of the eastern tropical Pacific: A review. Progress in Oceanography, 69(2-4), 101-142. https://doi.org/10.1016/j. pocean.2006.03.007

Amador, J. A., Durán-Quesada, A. M., Rivera, E. R., Mora, G., Sáenz, F., Calderón, B., \& Mora, N. (2016). The easternmost tropical Pacific. Part II: Seasonal and intraseasonal modes of atmospheric variability. Revista de Biología Tropical, 64(Supplement 1), S23-S57. https://doi.org/10.15517/rbt.v64i1.23409

Amador, J. A., Rivera, E. R., Durán-Quesada, A. M., Mora, G., Sáenz, F., Calderón, B., \& Mora, N. (2016). The easternmost tropical Pacific. Part I: A climate review. Revista de Biología Tropical, 64(Supplement 1), S1S22. https://doi.org/10.15517/rbt.v64i1.23407

Ballestero, D., \& Coen, J. E. (2004). Generation and propagation of anticyclonic rings in the Gulf of Papagayo. International Journal of Remote Sensing, 25(11), 2217-2224. https://doi.org/10.1080/0143116031000 1642395

Brenes, C. L., \& Gutiérrez, A. (1998). Oceanographic aspects of the Central American Pacific. Tópicos Meteorológicos y Oceanográficos, 5(1), 3-15.

Brenes, C., Hernández, A., \& Gutiérrez, A. (1998). Sea surface thermohaline variations along the Nicaraguan Pacific coastal waters. Tópicos Meteorológicos y Oceanográficos, 5(1), 17-27.

Brenes, C. L., Lavín, M. F., \& Mascarenhas, A. S., Jr. (2008). Geostrophic circulation between the Costa Rica Dome and Central America. Deep Sea Research Part I: Oceanographic Research Papers, 55(5), 608-629. https://doi.org/10.1016/j.dsr.2008.02.005

Chinchilla, G. (2011a). Resumen meteorológico abril de 2011. Boletín Meteorológico Mensual. Instituto Meteorológico de Costa Rica, San José, Costa Rica. https://www.imn.ac.cr/boletin-meteorologico

Chinchilla, G. (2011b). Resumen meteorológico agosto de 2011. Boletín Meteorológico Mensual. Instituto Meteorológico de Costa Rica, San José, Costa Rica. https://www.imn.ac.cr/boletin-meteorologico
Chinchilla, G. (2013). Resumen meteorológico abril de 2013. Boletín Meteorológico Mensual. Instituto Meteorológico de Costa Rica, San José, Costa Rica. https://www.imn.ac.cr/boletin-meteorologico

Chinchilla, G. (2014). Resumen meteorológico diciembre de 2014. Boletín Meteorológico Mensual. Instituto Meteorológico de Costa Rica, San José, Costa Rica. https://www.imn.ac.cr/boletin-meteorologico

Climate Prediction Center (n.d.). Cold \& Warm Episodes by Season. Retrieved February 26, 2021, from https://origin.cpc.ncep.noaa.gov/products/ analysis_monitoring/ensostuff/ONI_v5.php

Cortés, J. (2016). The Pacific coastal and marine ecosystems. In M. Kappelle (Ed.), Costa Rican Ecosystems (pp. 97-138). Chicago and London: University of Chicago Press. https://doi.org/10.7208/ chicago/9780226121642.003.0005

Cortés, J., Samper-Villarreal, J., \& Bernecker, A. (2014). Seasonal phenology of Sargassum liebmannii J. Agardh (Fucales, Heterokontophyta) in an upwelling area of the Eastern Tropical Pacific. Aquatic Botany, 119, 105-110. https://doi.org/10.1016/j. aquabot.2014.08.009

D'Croz, L., \& O'Dea, A. (2007). Variability in upwelling along the Pacific shelf of Panama and implications for the distribution of nutrients and chlorophyll. Estuarine, Coastal and Shelf Science, 73(1-2), 325340. https://doi.org/10.1016/j.ecss.2007.01.013

D’Croz, L., \& O’Dea, A. (2009). Nutrient and chlorophyll dynamics in Pacific Central America (Panama). Smithsonian Contributions to the Marine Sciences, 38, 335-344. https://doi.org/10.5479/si.01960768.38.73

D’Croz, L., \& Robertson, D. R. (1997). Coastal oceanographic conditions affecting coral reefs on both sides of the Isthmus of Panama. Proceedings of the 8th International Coral Reef Symposium, Panama, 2, 2053-2058.

Durán-Quesada, A. M., Sorí, R., Ordoñez, P., \& Gimeno, L. (2020). Climate perspectives in the IntraAmericas Seas. Atmosphere, 11(9), 959. https://doi. org/10.3390/atmos11090959

Fiedler, P. C., \& Lavín, M. F. (2017). Oceanographic conditions of the Eastern Tropical Pacific. In Glynn, P. W., Manzello, D. \& Enochs, I. (Eds.), Coral Reefs of the Eastern Pacific: Persistence and Loss in a Dynamic Environment. Coral Reefs of the World 8 (pp. 59-83). Dordrecht, NL: Springer. https://doi. org/10.1007/978-94-017-7499-4_3

Fiedler, P. C., \& Talley, L. D. (2006). Hydrography of the eastern tropical Pacific: A review. Progress in Oceanography, 69(2-4), 143-180. https://doi. org/10.1016/j.pocean.2006.03.008 
Jiménez, C., Bassey, G., Segura, Á., \& Cortés, J. (2010). Characterization of the coral communities and reefs of two previously undescribed locations in the upwelling region of Gulf of Papagayo (Costa Rica). Revista Ciencias Marinas y Costeras, 2(1), 95-108. https:// doi.org/10.15359/revmar.2.8

Kessler, W. S. (2006). The circulation of the eastern tropical Pacific: A review. Progress in Oceanography, 69(2-4), 181-217. https://doi.org/10.1016/j. pocean.2006.03.009

Levine, A. F., \& McPhaden, M. J. (2016). How the July 2014 easterly wind burst gave the 2015-2016 El Niño a head start. Geophysical Research Letters, 43(12), 6503-6510. https://doi.org/10.1002/2016gl069204

Loza-Álvarez, S., Benavides-Morera, R., Brenes-Rodríguez, C. L., \& Saxon Ballestero, D. (2018). Estructura del fitoplancton en las épocas seca y lluviosa en el golfo de Papagayo, Costa Rica. Revista Ciencias Marinas y Costeras, 9-30. https://doi.org/10.15359/ revmar.10-2.1

MATLAB $^{\circledR}$. (2018). version 9.4 (R2018a). Natick, Massachusetts: The MathWorks Inc.

McCreary, J. P., Lee, H. S., \& Enfield, D. B. (1989). The response of the coastal ocean to strong offshore winds: With application to circulations in the Gulfs of Tehuantepec and Papagayo. Journal of Marine Research, 47(1), 81-109. https://doi. org/10.1357/002224089785076343

Mora-Escalante, R. E., Lizano, O. G., Alfaro, E. J., \& Rodríguez, A. (2020). Distribución de temperatura y salinidad en campañas oceanográficas recientes en el Pacífico Tropical Oriental de Costa Rica. Revista de Biología Tropical, 68(Supplement 1), S177-S197. https://doi.org/10.15517/rbt.v68is1.41180

Morales-Ramírez, A., Till-Pons, I., Alfaro, E. J., Corrales-Ugalde, M. \& Sheridan-Rodríguez, C. (2021). Respuestas del mesozooplancton a condiciones oceanográficas en diferentes escalas en Bahía Salinas, Pacífico Norte de Costa Rica, durante 2011-2013. Revista de Biología Tropical, 60(Supplement 2), S142-S159.

Morera, R. (2011). Resumen meteorológico febrero de 2011. Boletín Meteorológico Mensual. Instituto Meteorológico de Costa Rica, San José, Costa Rica. https://www.imn.ac.cr/boletin-meteorologico

Morera, R. (2013a). Resumen meteorológico diciembre de 2013. Boletín Meteorológico Mensual. Instituto Meteorológico de Costa Rica, San José, Costa Rica. https://www.imn.ac.cr/boletin-meteorologico

Morera, R. (2013b). Resumen meteorológico febrero de 2013. Boletín Meteorológico Mensual. Instituto Meteorológico de Costa Rica, San José, Costa Rica. https://www.imn.ac.cr/boletin-meteorologico
Morera, R., \& Stolz, W. (2011). Resumen meteorológico junio de 2011. Boletín Meteorológico Mensual. Instituto Meteorológico de Costa Rica, San José, Costa Rica. https://www.imn.ac.cr/boletin-meteorologico

Naranjo, J. D. (2014). Estado del fenómeno ENOS, junio. Boletín Meteorológico Mensual. Instituto Meteorológico de Costa Rica, San José, Costa Rica. https:// www.imn.ac.cr/boletin-meteorologico

Poleo, D., \& Stolz, W. (2012a). Estado del fenómeno ENOS, agosto. Boletín Meteorológico Mensual. Instituto Meteorológico de Costa Rica, San José, Costa Rica. https://www.imn.ac.cr/boletin-meteorologico

Poleo, D., \& Stolz, W. (2012b). Resumen meteorológico agosto de 2012. Boletín Meteorológico Mensual. Instituto Meteorológico de Costa Rica, San José, Costa Rica. https://www.imn.ac.cr/boletin-meteorologico

Poleo, D., \& Stolz, W. (2013). Resumen meteorológico junio de 2013. Boletín Meteorológico Mensual. Instituto Meteorológico de Costa Rica, San José, Costa Rica. https://www.imn.ac.cr/boletin-meteorologico

Poleo, D., \& Stolz, W. (2014). Resumen meteorológico septiembre de 2014. Boletín Meteorológico Mensual. Instituto Meteorológico de Costa Rica, San José, Costa Rica. https://www.imn.ac.cr/ boletin-meteorologico

Quirós, E. (2009). Resumen meteorológico junio de 2009. Boletín Meteorológico Mensual. Instituto Meteorológico de Costa Rica, San José, Costa Rica. https:// www.imn.ac.cr/boletin-meteorologico

Rixen, T., Jiménez, C., \& Cortés, J. (2012). Impact of upwelling events on the sea water carbonate chemistry and dissolved oxygen concentration in the Gulf of Papagayo (Culebra Bay), Costa Rica: Implications for coral reefs. Revista de Biología Tropical, 60(Supplement 2), S187-S195. https://doi. org/10.15517/rbt.v60i2.20004

Roth, F., Stuhldreier, I., Sánchez-Noguera, C., Carvalho, S., \& Wild, C. (2017). Simulated overfishing and natural eutrophication promote the relative success of a non-indigenous ascidian in coral reefs at the Pacific coast of Costa Rica. Aquatic Invasions, 12(4), 435-446. https://doi.org/10.3391/ai.2017.12.4.02

Sánchez, M. (2008). Resumen meteorológico agosto de 2008. Boletín Meteorológico Mensual. Instituto Meteorológico de Costa Rica, San José, Costa Rica. https://www.imn.ac.cr/boletin-meteorologico

Sánchez-Noguera, C., Stuhldreier, I., Cortés, J., Jiménez, C., Morales, Á., Wild, C., \& Rixen, T. (2018). Natural ocean acidification at Papagayo upwelling system (north Pacific Costa Rica): implications for reef development. Biogeosciences, 15(8), 2349-2360. https:// doi.org/10.5194/bg-15-2349-2018 
Sea-Bird Electronics. (2011). Calculating Calibration Coefficients for WET Labs ECO-AFL and ECO-FL fluorometer, ECO-NTU turbidity meter, and ECO-FLNTU fluorometer/turbidity meter: Application note no. 62. https://www.seabird.com

Sea-Bird Electronics. (2013). SBE 43 Dissolved Oxygen Sensor: Application note no. 64. https://www.seabird. com

Sea-Bird Electronics. (2016). Seasoft V2 SBE Data Processing: Software manual. https://www.seabird.com

Sea-Bird Electronics. (n.d.). Glossary for Sea-Bird scientific training for data collection in the ocean. https:// www.seabird.com

Sibaja-Cordero, J. A., \& Cortés, J. (2008). Vertical zonation of rocky intertidal organisms in a seasonal upwelling area (Eastern Tropical Pacific). Revista de Biología Tropical, 56(Supplement 4), S91-S104. https://doi. org/10.15517/RBT.V56I4.27208

Solano, E. (2010). Resumen meteorológico octubre de 2010. Boletín Meteorológico Mensual. Instituto Meteorológico de Costa Rica, San José, Costa Rica. https://www.imn.ac.cr/boletin-meteorologico

Solano, E. (2012). Resumen meteorológico diciembre de 2012. Boletín Meteorológico Mensual. Instituto Meteorológico de Costa Rica, San José, Costa Rica. https://www.imn.ac.cr/boletin-meteorologico

Solano, E. (2014). Resumen meteorológico marzo de 2014 Boletín Meteorológico Mensual. Instituto Meteorológico de Costa Rica, San José, Costa Rica. https:// www.imn.ac.cr/boletin-meteorologico

Stuhldreier, I., Sánchez-Noguera, C., Rixen, T., Cortés, J., Morales, A., \& Wild, C. (2015). Effects of seasonal upwelling on inorganic and organic matter dynamics in the water column of eastern Pacific coral reefs. PLOS ONE, 10(11), e0142681. https://doi. org/10.1371/journal.pone.0142681

Stuhldreier, I., Sánchez-Noguera, C., Roth, F., Cortés, J., Rixen, T., \& Wild, C. (2015). Upwelling increases net primary production of corals and reef-wide gross primary production along the Pacific Coast of Costa Rica. Frontiers in Marine Science, 2, 113. https://doi. org/10.3389/fmars.2015.00113

Stuhldreier, I., Sánchez-Noguera, C., Roth, F., Jiménez, C., Rixen, T., Cortés, J., \& Wild, C. (2015). Dynamics in benthic community composition and influencing factors in an upwelling-exposed coral reef on the Pacific coast of Costa Rica. PeerJ, 3, e1434. https:// doi.org/10.7717/peerj.1434

Van Rossum, G., \& Drake, F. L. (2009). Python 3 Reference Manual. Scotts Valley, CA: CreateSpace.

Willett, C. S., Leben, R. R., \& Lavín, M. F. (2006). Eddies and tropical instability waves in the eastern tropical Pacific: A review. Progress in Oceanography, 69(2-4), 218-238. https://doi.org/10.1016/j. pocean. 2006.03 .010

Wizemann, A., Nandini, S. D., Stuhldreier, I., SánchezNoguera, C., Wisshak, M., Westphal, H., Rixen, T., Wild, C., \& Reymond, C. E. (2018). Rapid bioerosion in a tropical upwelling coral reef. PLOS ONE, 13(9), e0202887. https://doi.org/10.1371/journal. pone. 0202887

Zárate-Hernández, E. (2013). Climatología de masas invernales de aire frío que alcanzan Centroamérica y el Caribe y su relación con algunos índices Árticos. Tópicos Meteorológicos y Oceanográficos, 12, $35-55$. 